\title{
MICRO- AND ULTRASTRUCTURAL ASPECTS OF NORWAY SPRUCE TRACHEIDS: A REVIEW
}

by

\author{
Jonas Brändström \\ Wood Ultrastructure Research Centre (WURC), Department of Wood Science, \\ Swedish University of Agricultural Sciences, Box 7008, SE-750 07 Uppsala, Sweden
}

\begin{abstract}
SUMMARY
Norway spruce, Picea abies (L.) Karsten, is one of the most commercially important wood species in northern Europe. Wood from Norway spruce consists mainly ( $>90 \%$ ) of tracheids and the micro- and ultrastructure of these tracheids have a considerable effect on the wood and its manufactured products. This literature review presents current knowledge on some important aspects of the micro- and ultrastructural morphology of Norway spruce tracheids. At the microstructural level, variation and general trends within the tree are given for tracheid length, tracheid diameter and cell wall thickness. At the ultrastructural level, the architecture of the secondary cell wall, and particularly its lamellation and microfibril orientation are considered. Where information on Norway spruce tracheids was lacking, tracheids of other conifers are reviewed. Thus, this review also gives an insight on the structure of other conifer tracheids since there are many similarities in structure between different conifer species.
\end{abstract}

Key words: Microstructure, ultrastructure, tracheid morphology, cell wall, Picea abies.

\section{INTRODUCTION}

Norway spruce (Picea abies (L.) Karst.) is one of the most commercially important wood species in northern Europe. It is the most common species in Sweden, representing c. $44 \%$ of the standing volume of all tree species (National Board of Forestry 2000), and it is a very important raw material for both the pulp and paper- and the saw mill industries. Tracheids comprise over $90 \%$ of the total volume proportion of Norway spruce wood (Petrić \& Šćukanec 1973). The structure of these tracheids has a central role in the physical, chemical and mechanical properties of the wood, thereby influencing the final products manufactured. It is also important to have a great understanding about the micro- and ultrastructural characteristics of wood cells and their variation since there is an increasing interest in genetic engineering and tree breeding aiming to produce wood and fibres with improved properties.

The objective of this review is to focus on various micro- and ultrastructural features of Norway spruce axial tracheids, as treated in previous studies. Microstructural features are defined as those measured in micrometres and are visible by light micro- 
scopy (LM), features such as tracheid length, tracheid diameter and cell wall thickness. Ultrastructural features are defined as those measured in nanometres and are rendered visible by scanning and transmission electron microscopy (SEM and TEM) or atomic force microscopy (AFM), and indirect methods such as X-ray diffraction. Such features include cell wall lamellation and microfibril orientation. Cell wall features at higher resolution, such as the molecular structure of cellulose, are not reviewed. The review focuses on the morphology - not the physiology or chemistry of isolated tracheids in stem wood. Where information on Norway spruce tracheids was not found, tracheids of other trees, primarily of other species of Picea and secondarily of other conifers, are reviewed. In areas of research where views on cell wall morphology differ, for example secondary cell wall lamellation, studies on compression wood tracheids and hardwoods are also cited.

\section{Tracheid microstructure}

\section{Tracheid length}

The length of tracheids in conifers is closely related to the length of the fusiform cambial initials from which they are derived, since elongation during differentiation and maturation is limited. In Norway spruce elongation amounts to only approximately 9\% (Bailey 1920), and is thus not important in determining tracheid length. When the cambium expands in circumference cambial cells divide in a pseudotransverse (anticlinal) manner, generating two short cambial cells per pseudotransverse division. Tracheids derived from such cells are therefore also short (Bannan 1965). The percentage of fusiform initials dividing anticlinally is much larger on a thin tree compared to a tree with a large diameter since the circumferential expansion is relatively larger on a thin stem compared to a large stem, i.e. a large number of anticlinal divisions are required to maintain a continuous cambium on a thin tree. The percentage of fusiform initials dividing anticlinally rapidly decreases as the stem grows but when the stem radius is larger than about $6 \mathrm{~cm}$ the decrease is quite moderate. In addition, the rate at which short cambial initials either transform into ray cells or directly mature into tracheids without further subdivisions, increases towards the bark (Panshin \& De Zeeuw 1980). This radial change in anticlinal activity in the cambium results in a rapid increase in tracheid length in the juvenile wood and a more moderate increase in tracheid length in the mature wood, as shown in several studies (Helander 1933; Necesany 1961; Boutelje 1968; Marton et al. 1972; Atmer \& Thörnqvist 1982; Frimpong-Mensah 1987; Kucera 1994; Saranpää 1994; Herman et al. 1998; Saranpää et al. 2000).

Different radial patterns in tracheid length in mature wood have been reported. Necesany (1961) reported a continuous increase in tracheid length, while Atmer and Thörnquist (1982) and Kucera (1994) found a constant length after the maximum length had been reached. Helander (1933), on the other hand, reported a decrease near the bark in old trees. Herman et al. (1998) found that average tracheid length increased from pith to bark, and its variability increased exponentially (Fig. 1). These differences among trends in tracheid length reported for mature wood probably derive from differences in annual ring widths in the material examined. Bannan (1963) 


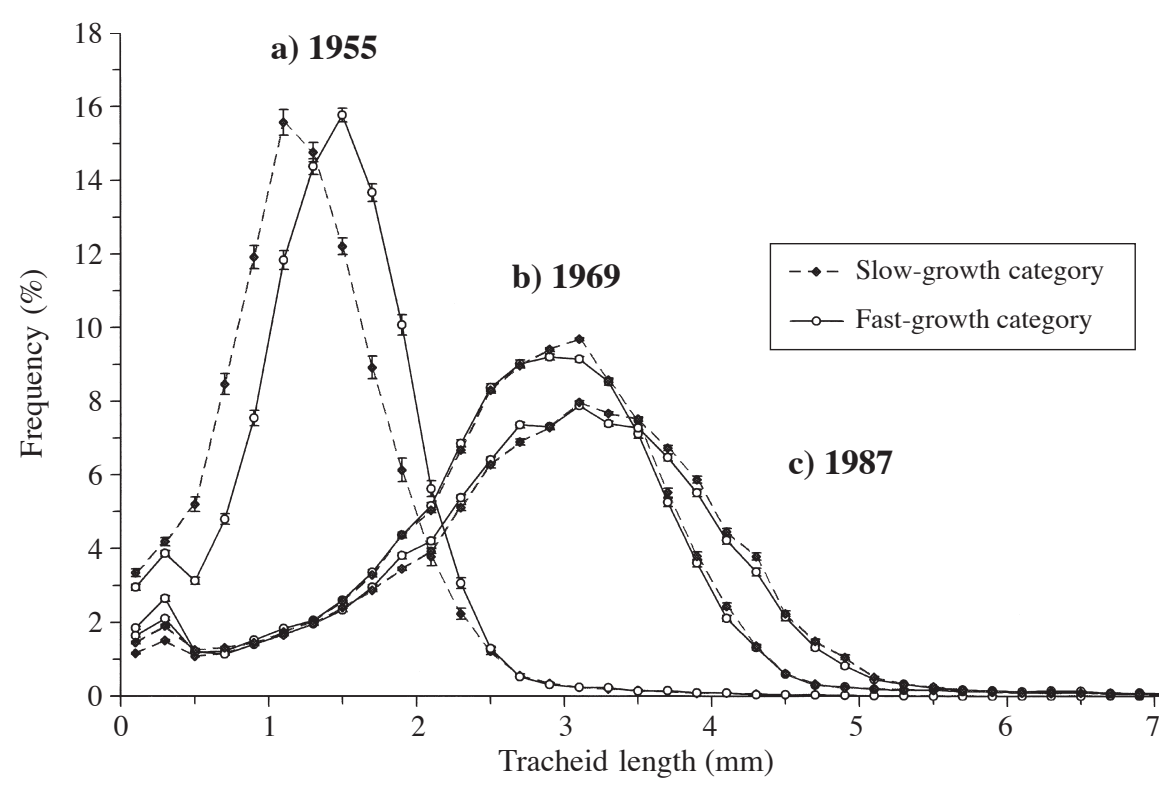

Fig. 1. Frequency distribution of tracheid length in fast-grown and slow-grown Norway spruce from a) a typical growth ring in the juvenile wood (1955) via b) the intermediate growth ring of 1969 (year of first thinning) to c) a typical growth ring in the mature wood (1987). The authors call it "the melting ice cream" (from Herman et al. 1998).

studied several species of Picea (excluding P. abies) and found that tracheid length reached its optimum in trees with annual rings of about 1-2 mm wide. In narrower and wider annual rings, anticlinal divisions were more frequent (Bannan 1967). Several studies have confirmed a negative relationship between wide annual rings and tracheid length in Norway spruce (Helander 1933; Nylinder \& Hägglund 1954; Frimpong-Mensah 1987; Herman et al. 1998; Saranpää et al. 2000). Bannan (1963, $1965,1967)$ explains this as an effect of an increased rate of anticlinal divisions in wider rings and that the anticlinal divisions takes place earlier in the growing season compared to annual rings of more moderate width. For example, in trees of Picea glauca with wide annual rings (7-9 mm) Bannan (1963) found that $43 \%$ of the anticlinal divisions occurred during the third quarter of the annual ring and $37 \%$ during the final quarter, while in annual rings of more moderate width $(2-3 \mathrm{~mm}), 37 \%$ of the anticlinal divisions occurred during the third quarter and $57 \%$ during the final quarter.

When discussing the effect of ring width (tree growth) on tracheid length it is also important to consider the distance from the pith since a constant ring width results in a relatively slower increase in circumference as the tree expands and thus a different number of anticlinal divisions. Fujiwara and Yang (2000) reported a negative relationship between circumferential growth rate and tracheid length for several conifers. Thus, ring width, number of annual rings from the pith (cambial age) and distance from the pith control tracheid length pattern from pith to bark. 
Within an annual increment, Norway spruce latewood tracheids are longer than earlywood tracheids (Helander 1933; Vasiljevic 1955; Frimpong-Mensah 1987). However, at the very end of the latewood, tracheid length decreases rapidly (Vasiljevic 1955; Bannan 1965). Bannan (1965) explains this by the fact that anticlinal divisions, in annual rings of moderate width, usually take place at the end of the growing season.

Several studies have also examined tracheid length along the stem. The shortest tracheids are generally found near the stump, with size increasing upwards until it reaches a maximum at approximately $40-50 \%$ of the total tree height (Helander 1933; Schultze-Dewitz \& Gotze 1973; Atmer \& Thörnqvist 1982; Kucera 1994). This pattern is much less pronounced in juvenile wood (Kucera 1994; Saranpää 1994).

\section{Tracheid radial and tangential diameter}

In contrast to tracheid length, tracheid width of Norway spruce has not been so intensively studied (Atmer \& Thörnqvist 1982; Tyrväinen 1995), and some studies only refer to "tracheid width" in general, while others discuss the difference between radial and tangential width. Generally, tracheids are narrower in juvenile than in mature wood (Boutelje 1968; Marton et al. 1972; Olesen 1977; Atmer \& Thörnqvist 1982; Kucera 1994; Lindström 1997; Saranpää et al. 2000) (see also Table 1), and the increase in tracheid width from pith to bark is more rapid in juvenile wood than in the mature part of the stem (Olesen 1977; Atmer \& Thörnqvist 1982; Kucera 1994; Saranpää et al. 2000). Olesen (1977) found the average tangential diameter to be c. 15 $\mu \mathrm{m}$ at any height of the tree. However, the increase in tracheid width with age was greater in the upper part of the stem, thus resulting in wider tracheids higher up in the same annual increment. Ring width and tracheid diameter have been shown to be correlated (i.e., wide annual rings = large tracheid diameter; Denne 1973; Lindström 1997; Saranpää et al. 2000). In earlywood, the radial width of tracheids normally exceeds the tangential width, but in fully developed latewood cells radial width is often much less than the tangential width (Table 2) (Fengel 1969).

When evaluating various studies on tracheid diameter it is important to remember that the results obtained depend on the method used. For example, some studies use microtomed cross sections (e.g. Kucera 1994; Lindström 1997), while others use macerations (e.g. Atmer \& Thörnqvist 1982). Since tracheid width varies along its axis (Lewis 1935; Keith 1975) the method used undoubtedly influences the results.

Table 1. Variation in tracheid properties (both latewood and earlywood) in Norway spruce juvenile and mature wood (from Boutelje 1968; Tyrväinen 1995).

\begin{tabular}{lll}
\hline Wood property & Juvenile wood & Mature wood \\
\hline Tracheid length $(\mathrm{mm})$ & $1.28-2.70$ & $2.80-4.29$ \\
Cell wall thickness $(\mu \mathrm{m})$ & $0.80-4.60$ & $2.10-7.53$ \\
Tracheid diameter $(\mu \mathrm{m})$ & $15.0-28.5$ & $29.3-39.7$ \\
\hline
\end{tabular}


Table 2. Wall thickness and tracheid diameter in earlywood and latewood of Norway spruce. * Ollinmaa (1961), ** Fengel (1969).

\begin{tabular}{lll}
\hline Wood property & Earlywood & Latewood \\
\hline Radial tracheid wall thickness $(\mu \mathrm{m}) *$ & 3.52 & 6.23 \\
Tangential tracheid wall thickness $(\mu \mathrm{m}) *$ & 2.90 & 4.69 \\
Radial tracheid diameter $(\mu \mathrm{m}) * *$ & 39.30 & 13.10 \\
Tangential tracheid diameter $(\mu \mathrm{m}) * *$ & 32.70 & 32.10 \\
\hline
\end{tabular}

\section{Cell wall thickness}

The most important difference between earlywood and latewood tracheids in Norway spruce and other conifers is probably the thickness of the $\mathrm{S}_{2}$-layer which is much thicker in latewood, both in absolute and relative terms (Fengel 1969; Fengel \& Stoll 1973) (see Table 3). Because the $S_{1}$ - and $S_{3}$-layers also increase in thickness, latewood tracheid walls are much thicker than earlywood tracheid walls (Fengel \& Stoll 1973; Gindl \& Wimmer 2000) but at the very end of the latewood, cell wall thickness often decreases (Denne 1973; Gindl \& Wimmer 2000).

The cell wall thickness of Norway spruce tracheids increases from pith to bark (Table 1) (Marton et al. 1972). This is because latewood percentage increases with age (Kucera 1994; Lindström 1997). Studies on the variation of cell wall thickness with stem height are limited, though Tyrväinen (1995) concluded that, on average, thickness decreases with tree height.

Ollinmaa (1961) showed that radial walls of Norway spruce tracheids are thicker than tangential walls (Table 2), and that cell wall thickness also varies along the length of a tracheid. Ladell (1967) studied a number of conifer species, including Picea mariana, and showed that the tangential wall tended to be 1.6 to $13.6 \%$ thicker in areas of ray crossing than in areas without ray crossings. The thickening increased from pith to bark and it was more pronounced at increased growth rates. He suggested that the increase was due to additional deposition of cell wall material on the tangential walls of tracheids at ray contact areas. However, Keith (1975) studied the thickening on Pinus resinosa and Thuja occidentalis and concluded that the increase in thickness of the tangential walls is not due to an additional deposition of cell wall material. Instead, the increase in thickness of the tangential walls is proportional to the reduction in tangential width of the tracheid and to the tangential width of the ray, resulting in decreased lumen size of the tracheid.

As discussed above with reference to tracheid diameter, the method used to investigate a morphological parameter will undoubtedly influence the results obtained. Donaldson and Lausberg (1998) showed that light microscopy overestimated wall thickness by up to $50 \%$ and underestimated lumen area by $4 \%$ in a study comparing confocal laser scanning (CLSM) and light microscopy. 


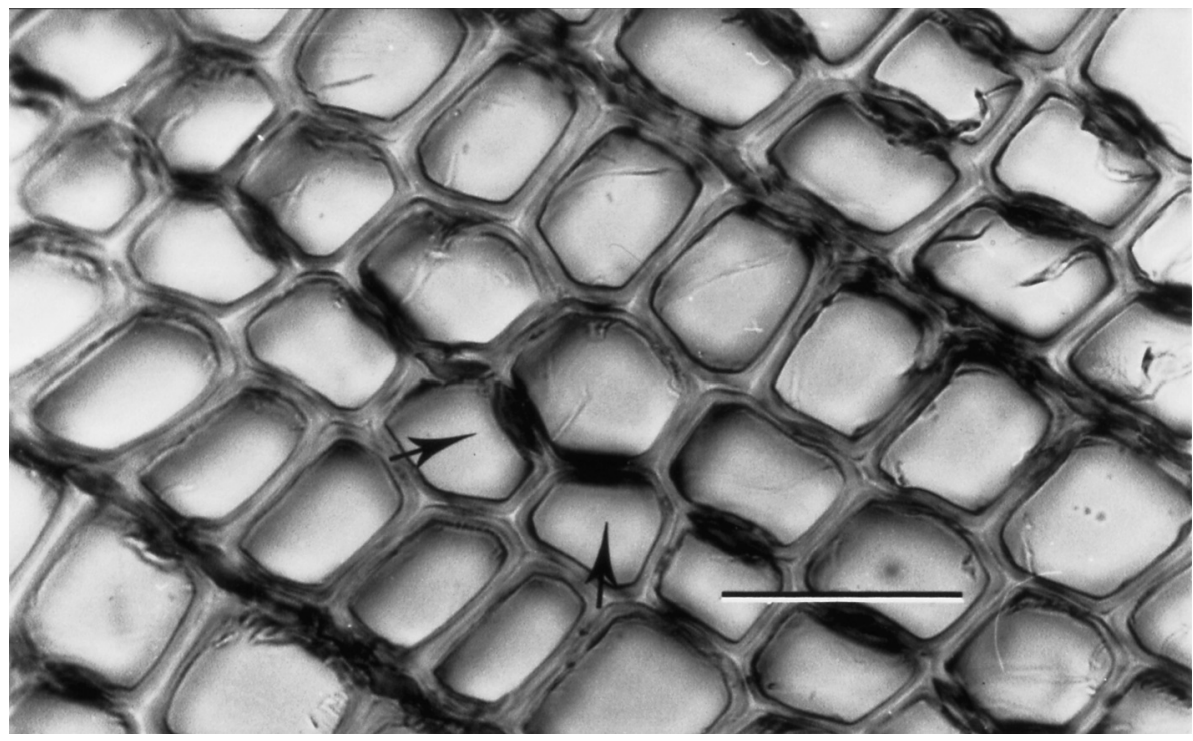

Fig. 2. Cross section of Norway spruce (Picea abies) showing a radial wall divided by a corner. Bordered pits (arrows) on both sides of the corner. - Scale bar $=50 \mu \mathrm{m}$.

\section{Geometry of tracheids}

In addition to length and width, it is also relevant to discuss tracheid geometry. An idealised model of a conifer tracheid is the stretched 14-sided polyhedron ( 8 hexagonal faces and 6 square faces) (Lewis 1935). The 14-sided polyhedron, also called tetrakaidechaedron or truncated octahedron, fills space when assembled. In nature, wide variations of this model occur, displaying, among other features, bifurcated and distorted tracheid tips (Wardrop 1969). In idealised cell wall models, a tracheid is normally shown with four sides. However, cross sections of wood often show tracheids with more than four sides, especially in earlywood. Sometimes the radial wall is divided into two sides separated by a corner with bordered pits occurring in both walls (Fig. 2).

Table 3. Cell wall thickness of Norway spruce. Absolute values $(\mu \mathrm{m})$, measured on radial walls, and percent of the different parts of the cell wall described in the text (from Fengel \& Stoll 1973).

\begin{tabular}{lccccc}
\hline \multirow{2}{*}{$\begin{array}{l}\text { Cell wall } \\
\text { layer }\end{array}$} & \multicolumn{2}{c}{ Absolute value $(\mu \mathrm{m})$} & & \multicolumn{2}{c}{ Percent $(\%)$} \\
\cline { 2 - 3 } \cline { 5 - 6 } Carlywood & Latewood & & Earlywood & Latewood \\
\hline $\mathrm{CML}$ & $0.05-\mathbf{0 . 0 9 - 0 . 1 6}$ & $0.04-\mathbf{0 . 0 9 - 0 . 1 6}$ & & $2.7-\mathbf{4 . 2}-9.5$ & $1.0-\mathbf{2 . 1}-5.8$ \\
$\mathrm{~S}_{1}$ & $0.12-\mathbf{0 . 2 6}-0.40$ & $0.19-\mathbf{0 . 3 8}-0.71$ & & $5.9-\mathbf{1 2 . 5}-21.8$ & $4.9-\mathbf{9 . 0}-16.6$ \\
$\mathrm{~S}_{2}$ & $0.91-\mathbf{- 1 . 6 6}-2.32$ & $1.50-\mathbf{3 . 6 9}-5.60$ & & $68.2-\mathbf{7 8 . 7}-87.8$ & $72.5-\mathbf{8 5 . 4 - 9}-91.3$ \\
$\mathrm{~S}_{3}$ & $0.02-\mathbf{0 . 0 9}-0.19$ & $0.01-\mathbf{0 . 1 4}-0.36$ & & $0.9-\mathbf{4 . 5}-10.1$ & $0.4-\mathbf{3 . 3}-7.2$ \\
Total & $\mathbf{2 . 1}$ & $\mathbf{4 . 3}$ & & $\mathbf{9 9 . 9}$ & $\mathbf{9 9 . 8}$ \\
\hline
\end{tabular}




\section{Trabeculae}

Trabeculae are intracellular bar-like structures extending radially across the tracheid lumen from tangential walls. Trabeculae are more common in wounded and compression wood than in wood without anomalies (Grosser 1986). Grosser (1986) studied Norway spruce and concluded that trabeculae are formed to prevent collapse of the cambial initials and since irregularities also occur in normal anticlinal and periclinal divisions of the fusiform initials, they can also occur in normal wood.

\section{Tracheid ultrastructure}

\section{Cell wall architecture and cell wall layers}

The cell wall of tracheids consists of the layers; the primary wall $(\mathrm{P})$, the outer layer of the secondary wall $\left(\mathrm{S}_{1}\right)$, the middle layer of the secondary wall $\left(\mathrm{S}_{2}\right)$ and the inner layer of the secondary wall $\left(\mathrm{S}_{3}\right)$. The layers have different thickness (Table 3) and cellulose microfibril orientation. The microfibril orientation (or angle) is the angle between the microfibrils and the tracheid axis. The letters $\mathrm{Z}$ and $\mathrm{S}$ are often used to describe the helical orientation of microfibrils in tracheid walls with $\mathrm{Z}$ indicating right-handed and $S$ indicating left-handed orientations. Intermediate layers may lie between the cell wall layers (for a review see Wardrop 1964; Harada \& Côté Jr 1985) and the cell wall may also have a helicoidal texture (see Roland et al. 1987). Within a cell wall layer, lamellae are present. There is no clear definition in the literature of lamella or lamellation. Generally, a lamella is regarded as a concentric agglomeration of cellulose microfibrils within a hemicellulose-lignin matrix but depending on what microscopical method is used the size observed and texture of the lamella will vary. Below, lamellation is discussed in the cell wall layers. In this review these lamella should be seen in the general view discussed above.

Many researchers have attempted to summarise the cell wall structure of tracheids into a single model (e.g. Wardrop \& Harada 1965; Dunning 1969; Sell \& Zimmerman 1993) with a specific structural pattern. These models are generalised and do not indicate actual variation and the structure of the cell is often shown as a small region which is not specified from where along the tracheid or from where in the tree the cell wall and tracheid are taken.

The cell wall of tracheids are highly variable and complex. Abe et al. (1991) studied Abies sachaliensis and reported a gradual shift in microfibrillar orientation in the secondary wall from $S_{1}$ to $S_{3}$. Abe et al. $(1995 a, b)$ later found that the orientations of cortical microtubules and cellulose microfibrils were correlated, strongly supporting the hypotheses that microtubules direct the orientation of cellulose microfibrils within the growing cell wall (see Ledbetter \& Porter 1963; Prodhan et al. 1995; Wymer \& Lloyd 1996; Funada et al. 2000). However, some researchers have questioned the correlation between microtubules and microfibrils (Emons et al. 1992), proposing an alternative hypothesis, the geometrical model, based on microfibril deposition (Emons 1994; Emons \& Mulder 1998, 2000). In the geometrical model, cellulose microfibril deposition is controlled by the density of active cellulose synthases in the plasma membrane, the distance between individual microfibrils within a wall lamella and the geometry of the cell (Emons \& Mulder 2000). 


\section{Compound middle lamella}

The compound middle lamella (CML) lies between adjoining tracheids and acts essentially as a cementing agent. The lamella, lying between two primary walls of adjacent tracheids, is called the true middle lamella. When lignification occurs, the distinction between the primary cell walls of adjoining cells and the intervening middle lamella is virtually lost, and the three layers collectively form the compound middle lamella. The microfibrils in the primary wall of conifers are irregular in orientation. It has been found that the microfibrils in the outer surface of the primary wall are oriented approximately axially and the innermost surface approximately transversely (Wardrop 1958, 1964; Harada \& Côté Jr 1985). This was confirmed recently by Abe et al. (1995b; 1997) in differentiating tracheids of Abies sachaliensis. Using TEM on ultra-thin sections of Norway spruce tracheids Maurer and Fengel (1991) showed that the strongly lignified compound middle lamella also includes the outer part of the $\mathrm{S}_{1}$-layer, i.e. the outer part of the $\mathrm{S}_{1}$-layer may on occasions be strongly lignified.

\section{The $S_{1}$-layer}

Approximately $0.3 \mu \mathrm{m}$ or c. $10 \%$ (Fengel \& Stoll 1973) of the cell wall is comprised of the $\mathrm{S}_{1}$-layer (Table 3), and since it is rather thin considerable technical difficulties arise when determining the organisation of this layer. Kerr and Bailey (1934) and later Bailey and Vestal (1937) used polarised light and iodine precipitation to conclude that microfibrils in the $\mathrm{S}_{1}$-layer are oriented nearly perpendicular to the tracheid axis. Later, it was shown that $S_{1}$ consists of two striations of cellulose microfibrils with alternate helical orientation, i.e. both $\mathrm{S}$ and $\mathrm{Z}$ helices - the so-called crossed fibrillar structure (Emerton \& Goldsmith 1956; Frei et al. 1957; Wardrop 1957; Jurbergs 1960; Dunning 1969; Tang 1973; Abe et al. 1991; Kataoka et al. 1992). However, Khalili et al. (2001) did not observe such crossed structure in Pinus sylvestris tracheids attacked by soft rot fungi. Paakkari and Serimaa (1984) studied the microfibril angle in the $\mathrm{S}_{1}$-layer of Norway spruce and reported $54^{\circ}$ for earlywood and $46^{\circ}$ in latewood. Meier (1955) reported microfibrils to be oriented mainly in a S-direction close to $90^{\circ}$ in Norway spruce tracheids. Emerton and Goldsmith (1956) claimed that there were non-spiralling fibrils at the corners of conifer tracheids in the $\mathrm{S}_{1}$-layer which was rejected by Wardrop (1957).

\section{The $S_{2}$-layer, lamellation}

Since about $80 \%$ (Table 3) of the cell wall of Norway spruce (an even greater proportion in latewood) is comprised of the $S_{2}$-layer (Fengel \& Stoll 1973), it is easier to characterise chemically and microscopically compared with the other wall layers. Some studies have claimed that the $\mathrm{S}_{2}$-layer of softwoods does not consist of lamellae (Chafe 1974), but the general consensus is that this layer consists of several concentric lamellae (Wardrop 1964; Stone et al. 1971; Kerr \& Goring 1975; Ruel et al. 1978; Daniel \& Nilsson 1984; Maurer \& Fengel 1991; Hanley \& Gray 1994) (Fig. 3).

Some recent studies have reported the $\mathrm{S}_{2}$-layer to have some kind of radial lamellation (Sell \& Zimmerman 1993; Sell 1994b; Larsen et al. 1995; Singh 1997; Schwarze \& Engels 1998; Singh et al. 1998; Singh \& Donaldson 1999; Zimmermann 


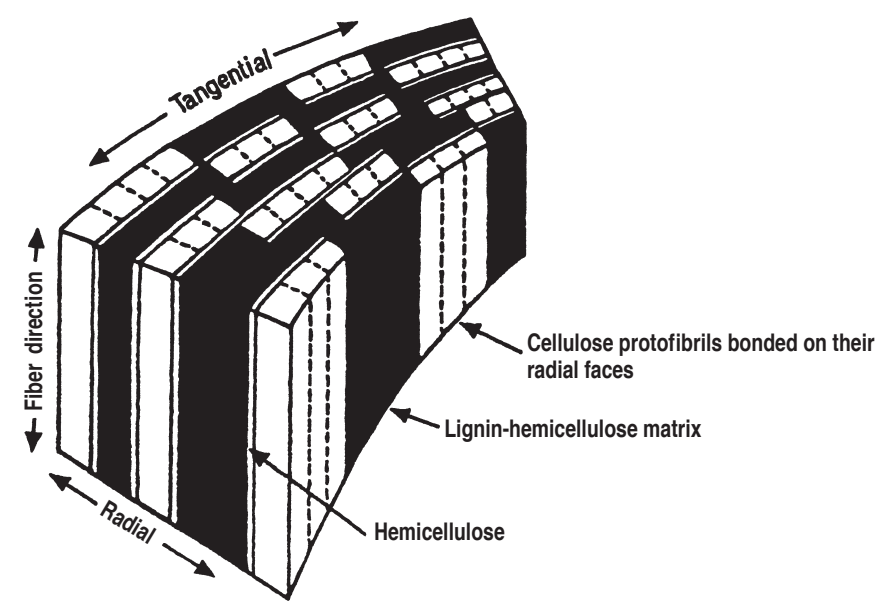

Fig. 3. Proposed ultrastructural model for the arrangement of lignin, cellulose and hemicellulose in the $\mathrm{S}_{2}$-layer of the wood cell wall (from Kerr \& Goring 1975).

\& Sell 2000; Singh \& Daniel 2001). The idea of radial lamellation in conifers is not new, and was discussed earlier by Bailey (1938) and also found in compression wood by Wardrop and Dadswell (1950). Sell and Zimmermann (1993) used Field Emission-SEM (FE-SEM) to study transverse-fracture surfaces of longitudinally tensionloaded wood of Norway spruce. They exhibited radial, or approximately radial, agglomerations of the $\mathrm{S}_{2}$-layer. To prove that these tension-fracture surfaces were not artefacts, Sell (1994b) studied microsections of Abies alba using light microscopy and verified the radial structure. He proposed a sandwich-like model of the cell wall; the thick $\mathrm{S}_{2}$-layer acting as a stiffening core and the thinner $\mathrm{S}_{1^{-}}$and $\mathrm{S}_{3}$-layers acting as faces (Sell 1994a). He also concluded that a sandwich-like cell wall, as opposed to concentric lamellation, would benefit the mechanical properties of the whole tree. Moreover, a sandwich-like cell wall would increase bending stiffness against wind and gravity and it would also be beneficial for the resistance to water tension in the tracheids (Booker \& Sell 1998). The idea of radial lamellation has been supported by others using different kinds of wood rotting fungi (Larsen et al. 1995; Schwarze \& Engels 1998). The latter authors used white rot to form cavities in blocks of Norway spruce. These cavities appeared to be separated radially. Larsen et al. (1995) studied southern pine (Pinus spp.) exposed to brown rot fungi and they also concluded that thin radial bands of hemicellulose lie adjacent to the crystalline microfibril bundles. Using the results of Sell and Zimmermann (1993) they presented a new model of the $\mathrm{S}_{2}$-layer (Fig. 4), to be compared to the model of Kerr and Goring (1975) (Fig. 3). The presence of radial features in the $\mathrm{S}_{2}$-layer in tracheids of normal and mild compression wood of Pinus radiata (Singh et al. 1998; Singh \& Donaldson 1999) and in normal wood of Norway spruce (Singh \& Daniel 2001) has been confirmed by TEM of ultra-thin sections. These researchers have shown nano-level lignin inhomogeneity in sinuous radial profiles across the thickness of the $S_{2}$-layer, and on the basis of 


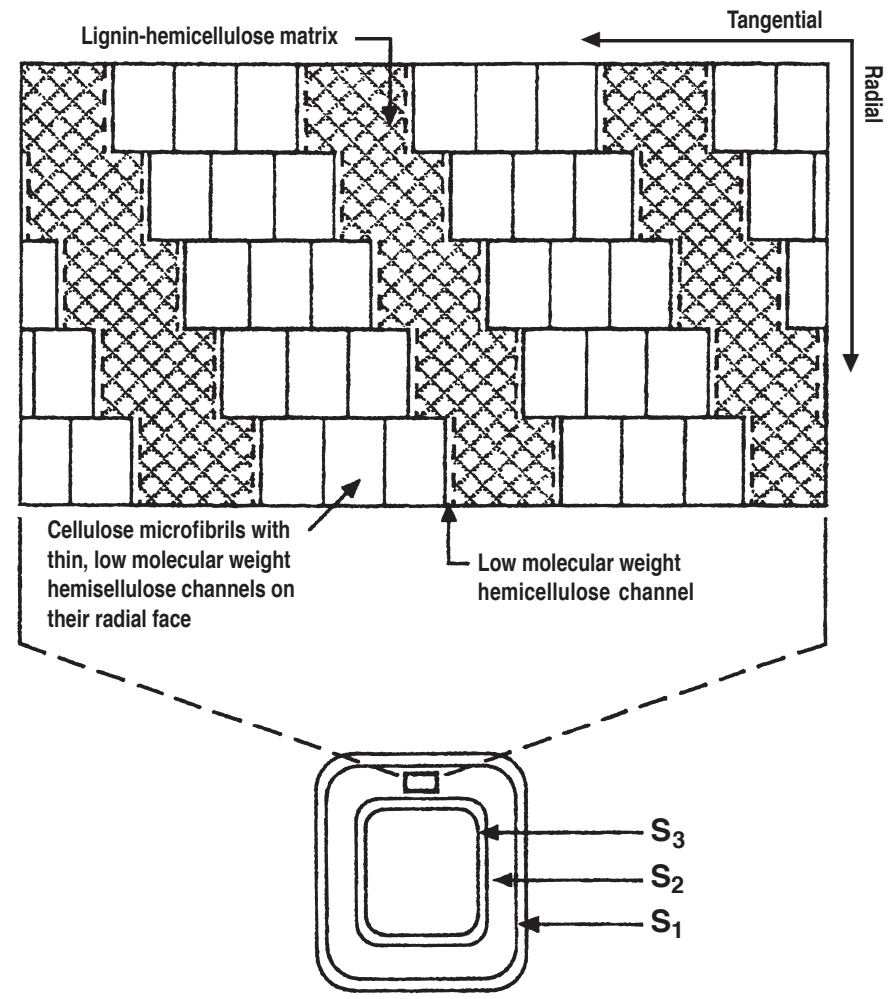

Fig. 4. Proposed ultrastructural model for the arrangement of lignin, cellulose and hemicellulose in the $\mathrm{S}_{2}$-layer of the wood cell wall (from Larsen et al. 1995).

this pattern of lignin micro-distribution they have predicted that the microfibrillar bundles are randomly distributed across the $\mathrm{S}_{2}$-layer.

However, the idea of radial lamellation of the $S_{2}$-layer of conifer tracheids has been criticised. One objection to the results obtained by Sell and co-workers is that the FE-SEM (Sell \& Zimmerman 1993; Sell 1994a) and LM images provided (Sell 1994b) do not show the cell wall at high enough resolution, thus the radial agglomerations could be artefacts. This was recently shown by Fahlén and Salmén (2001) who used the same fracture method as Sell and Zimmermann (1993) on Norway spruce wood but Fahlén and Salmén (2001) used Atomic Force Microscopy (AFM) instead and sectioned the fracture surface down to the unchanged cell wall, and they observed that the radial structure of the cell wall near the fracture surface changed to concentric in the unaffected part of the cell wall. Furthermore, if the cell wall of conifer tracheids has a radial structure, studies on the cellulose microfibril deposition of the $\mathrm{S}_{2}$-layer during differentiation of tracheids would show radial bands of newly deposited cellulose microfibrils. However, such studies using FE-SEM (Abe et al. 1991; Abe et al. 1995a; Prodhan et al. 1995; Abe et al. 1997) have not shown such 
structures. Moreover, recent studies using high-resolution techniques such as rapidfreezing and deep etching (Nakashima et al. 1997; Fujino \& Itoh 1998; Hafrén et al. 1999) showed no evidence of radial agglomerations of cellulose microfibrils.

\section{The $S_{2}$-layer, microfibril angle}

Microfibrils are considered to be oriented in a Z-helix in the $\mathrm{S}_{2}$-layer (Wardrop 1964; Harada \& Côté Jr 1985), though some studies claim varying and undulating orientations of microfibrils. Pyszynski and Hejnowicz (1972) studied the fibrillar direction in Norway spruce tracheids using the orientation of cross-field pits. They found that the majority $(80 \%)$ of the trees studied had a Z-helix with an angle of more than $10^{\circ}$, and that this orientation occurred regardless of the type of wood grain. In the remaining $20 \%$, the angle was steeper and undulations of the orientation occurred. Khalili et al. (2001) studied soft rot cavities in Pinus sylvestris tracheids and reported occasional S-helices in the $\mathrm{S}_{2}$-layer. Abe et al. (1991) studied Abies sachaliensis and reported a gradual clockwise (seen from the lumen side) shift of microfibril orientation from the outer $S_{1}$ to the middle of $S_{2}$ and then counterclockwise to the innermost $\mathrm{S}_{3}$.

There have been several studies on the microfibril angle in the $S_{2}$-layer of Norway spruce tracheids; Table 4 gives an overview of the results. Results obtained show considerable variation. These differences are likely related to the method used, but genetic and environmental factors also influence microfibril angle. However, some general trends can be recognised. Microfibril angle has been shown to decrease from pith to bark in Norway spruce (Lindgren 1958; Necesany 1961; Kantola \& Seitsonen 1969; Marton et al. 1972; Sahlberg et al. 1997; Lindström et al. 1998; Saranpää et al. 1998; Saranpää et al. 2000), the decrease being more rapid in juvenile than in mature wood (Lindgren 1958; Sahlberg et al. 1997; Lindström et al. 1998; Saranpää et al. 1998). Studies have also examined the relationship between microfibril angle and annual ring width. Fast growing trees with large annual rings have been shown to have larger microfibril angles compared with trees with small annual rings (Kyrkjeeide 1990; Herman et al. 1999; Saranpää et al. 2000). This phenomenon has been shown to suppress the general trend of decreasing microfibril angle from pith to bark. Kyrkjeeide (1990) used the orientation of cross-field pits and reported an increase in angle from $45-50^{\circ}$ in juvenile wood to about $55^{\circ}$ in mature wood in earlywood of dominant trees. A similar result was obtained by Herman et al. (1999), using the same method. Herman et al. (1999) reported that the microfibril angle increased in fast-growing trees from $26^{\circ}$ in the juvenile wood (i.e. before first thinning) to $29^{\circ}$ in mature wood (i.e. after first thinning). However, the use of pit aperture as a measure of microfibril angle has been questioned. In a study of pit orientation, Sirviö and Kärenlampi (1998) concluded that the angular orientation of pits is not a simple function of microfibril angle since they found almost all types of pit angular orientations. Use of pit apertures is also thought to result in overestimated microfibril angles for earlywood tracheids (Huang et al. 1998).

Results concerning the variability and trends of microfibril angle within annual rings of Norway spruce have been shown to depend largely on the methods used. 
Table 4. Mean microfibril angle in the $S_{2}$-layer of Norway spruce tracheids determined by different methods.

\begin{tabular}{|c|c|c|c|c|}
\hline Study & Type of tracheid & Angle & Method & $\begin{array}{l}\text { Age } \\
\text { of tree }\end{array}$ \\
\hline (Ollinmaa 1961) & average tree & $25.5^{\circ}$ & polarised light & $35-45$ \\
\hline (Kantola \& Kähkönen 1963) & $8^{\text {th }}$ annual ring & $13^{\circ}$ & X-ray & 45 \\
\hline (Kantola \& Seitsonen 1969) & $\begin{array}{l}3^{\text {rd }} \text { annual ring } \\
3^{\text {rd }} \text { annual ring } \\
3^{\text {rd }} \text { annual ring } \\
\text { last annual ring } \\
\text { last annual ring } \\
\text { last annual ring }\end{array}$ & $\begin{array}{l}18.4^{\circ} \\
19.2^{\circ} \\
39.6^{\circ} \\
7.2^{\circ} \\
5.4^{\circ} \\
20.4^{\circ}\end{array}$ & $\begin{array}{l}\text { X-ray }(002) \\
\text { X-ray }(002) \\
\text { X-ray }(002) \\
\text { X-ray }(002) \\
\text { X-ray }(002) \\
\text { X-ray }(002)\end{array}$ & $\begin{array}{l}94 \\
100 \\
214 \\
94 \\
100 \\
214\end{array}$ \\
\hline (Marton \& McGovern 1970) & $\begin{array}{l}\text { earlywood } \\
\text { latewood } \\
\text { earlywood } \\
\text { latewood }\end{array}$ & $\begin{array}{l}20.4^{\circ} \\
18.1^{\circ} \\
11.5^{\circ} \\
12^{\circ}\end{array}$ & $\begin{array}{l}\text { polarised light } \\
\text { polarised light } \\
\text { X-ray }(002) \\
\text { X-ray }(002)\end{array}$ & \\
\hline (Marton et al. 1972) & $\begin{array}{l}29^{\text {th }} \text { annual ring (earlywood) } \\
29^{\text {th }} \text { annual ring (latewood) } \\
27^{\text {th }} \text { annual ring (earlywood) } \\
27^{\text {th }} \text { annual ring (latewood) } \\
1^{\text {st }} \text { annual ring (earlywood) } \\
1^{\text {st }} \text { annual ring (latewood) }\end{array}$ & $\begin{array}{l}18.3^{\circ} \\
23.5^{\circ} \\
14.3^{\circ} \\
9.8^{\circ} \\
27.5^{\circ} \\
29.3^{\circ}\end{array}$ & $\begin{array}{l}\text { X-ray }(002) \\
\text { X-ray }(002) \\
\text { X-ray }(002) \\
\text { X-ray }(002) \\
\text { X-ray }(002) \\
\text { X-ray }(002)\end{array}$ & $\begin{array}{l}29 \\
29 \\
29 \\
29 \\
29 \\
29\end{array}$ \\
\hline (Paakkari \& Serimaa 1984) & $\begin{array}{l}\text { earlywood } \\
\text { latewood }\end{array}$ & $\begin{array}{l}4.9^{\circ} \\
4.3^{\circ}\end{array}$ & $\begin{array}{l}\text { X-ray (002) } \\
\text { X-ray (002) }\end{array}$ & \\
\hline (Kyrkjeeide 1990) & $\begin{array}{l}\text { earlywood } \\
\text { latewood }\end{array}$ & $\begin{array}{l}40-60^{\circ} \\
5-20^{\circ}\end{array}$ & $\begin{array}{l}\text { orientation of } \\
\text { c.f. pits } \\
\text { orientation of } \\
\text { c.f. pits }\end{array}$ & $\begin{array}{l}30 \\
30\end{array}$ \\
\hline (Jakob et al. 1994) & $\begin{array}{l}\text { earlywood } \\
\text { latewood }\end{array}$ & $\begin{array}{l}4.6^{\circ} \\
19.8^{\circ}\end{array}$ & $\begin{array}{l}\text { SAXS } \\
\text { SAXS }\end{array}$ & \\
\hline (Sahlberg et al. 1997) & $\begin{array}{l}\text { earlywood } \\
\text { latewood } \\
\text { average }\end{array}$ & $\begin{array}{l}9.7^{\circ} \\
5.1^{\circ} \\
8.3^{\circ}\end{array}$ & $\begin{array}{l}\text { X-ray }(040) \\
\text { X-ray }(040) \\
\text { Iodine cracks }\end{array}$ & $\begin{array}{l}100 \\
100 \\
100\end{array}$ \\
\hline (Saranpää et al. 1998) & $\begin{array}{l}5^{\text {th }} \text { annual ring (earlywood) } \\
5^{\text {th }} \text { annual ring (earlywood) } \\
14^{\text {th }} \text { annual ring (earlywood) } \\
14^{\text {th }} \text { annual ring (earlywood) } \\
20^{\text {th }} \text { annual ring (earlywood) } \\
20^{\text {th }} \text { annual ring (earlywood) }\end{array}$ & $\begin{array}{l}28^{\circ} \\
22^{\circ} \\
13^{\circ} \\
14.5^{\circ} \\
12^{\circ} \\
14^{\circ}\end{array}$ & $\begin{array}{l}\text { polarised light } \\
\text { X-ray }(040) \\
\text { polarised light } \\
\text { X-ray (002) } \\
\text { polarised light } \\
\text { X-ray (002) }\end{array}$ & \\
\hline (Herman et al. 1999) & $\begin{array}{l}\text { earlywood } \\
\text { latewood } \\
\text { mean of slow-grown trees } \\
\text { mean of fast-grown trees }\end{array}$ & $\begin{array}{l}43^{\circ} \\
7^{\circ} \\
21^{\circ} \\
26^{\circ}\end{array}$ & $\begin{array}{l}\text { orientation of } \\
\text { c.f. pits } \\
\text { orientation of } \\
\text { c.f. pits } \\
\text { orientation of } \\
\text { c.f. pits } \\
\text { orientation of } \\
\text { c.f. pits }\end{array}$ & \\
\hline (Lichtenegger et al. 1999) & $\begin{array}{l}\text { earlywood } \\
\text { latewood }\end{array}$ & $\begin{array}{l}0^{\circ} \\
19.9^{\circ}\end{array}$ & $\begin{array}{l}\text { SAXS } \\
\text { SAXS }\end{array}$ & \\
\hline
\end{tabular}


$\mathrm{X}$-ray diffraction is a rapid method frequently used in microfibril angle research, but since the X-ray beam covers many tracheids (and also ray cells) this method gives only an average result from many tracheids. This approach yields the small differences between earlywood and latewood obtained in several studies (Paakkari \& Serimaa 1984; Sahlberg et al. 1997; Bergander et al. 2001). Microscopical methods that enable measuring of individual tracheids have revealed great variability within annual rings and a rapid decrease in microfibril angle from earlywood to latewood (Herman et al. 1999; Bergander et al. 2001). However, other studies using smallangle X-ray scattering (SAXS) on Norway spruce tracheids (Jakob et al. 1994; Reiterer et al. 1998; Lichtenegger et al. 1999) (Table 4) have reported a much larger microfibril angle in latewood than in earlywood tracheids. The microfibril angle may also vary within the $\mathrm{S}_{2}$-layer of conifers (Abe et al. 1991; Kataoka et al. 1992; Bergander et al. 2001; Khalili et al. 2001). Khalili et al. (2001) and Bergander et al. (2001) have examined the orientation of soft rot cavities in Pinus sylvestris and Norway spruce respectively, reporting a variation in cavity orientation within restricted parts of the tracheid cell wall.

It has been assumed that the tracheid length and fibril angle of Norway spruce are correlated (i.e., short tracheids = large microfibril angle, Preston 1934; Necesany 1961; Kantola \& Seitsonen 1969; Marton et al. 1972). However, these studies are based on comparisons between the properties of juvenile and mature wood, in other words, comparisons between fundamentally different tracheid types. If only the mature wood is considered, the fibril angle has been shown to be fairly constant in Norway spruce (Necesany 1961; Kantola \& Seitsonen 1969; Marton et al. 1972; Sahlberg et al. 1997; Saranpää et al. 1998), though tracheid length is known to increase in the mature wood (Necesany 1961; Atmer \& Thörnqvist 1982; Kucera 1994). Moreover, it has been suggested that the increase in length of tracheids from the cambium to the xylem would entail stretching of microfibrils and thus smaller fibril angles. This is unlikely since tracheid lengthening is limited, to c. $9 \%$ in Norway spruce (Bailey 1920) and, secondly and more convincingly, tracheid expansion ceases as the secondary wall is being formed (Abe et al. 1997). Hirakawa and Fujisawa (1995) found no correlation between fibril angle and tracheid length in a study on Cryptomeria japonica. In addition, the microfibril angle has been shown to decrease rapidly from earlywood to latewood (as mentioned above), while tracheid length has been shown to increase moderately from earlywood to latewood. Despite this, there may be some relationship between tracheid length and microfibril angle since these parameters behave in the same way from pith to bark, and also between wide and narrow annual rings as discussed above.

Several studies have claimed that the microfibril angle in the tangential walls of conifer tracheids is smaller than in the radial walls (Preston 1934; Tang 1973; Khalili et al. 2001). However, Bergander and Salmén (2000) found no significant difference between radial and tangential walls in both latewood and earlywood of Norway spruce tracheids using polarisation confocal microscopy. 


\section{The $S_{3}$-layer}

The innermost layer of the cell wall is called the $\mathrm{S}_{3}$-layer or sometimes, in older literature, the tertiary wall. It is a thin layer, c. $0.1 \mu \mathrm{m}$ in thickness, representing $4 \%$ of the cell wall (Fengel \& Stoll 1973) (Table 3). However, the thickness of the $\mathrm{S}_{3}$ layer may vary considerably, as discussed by Singh and Booker (2000) after studies on Pinus radiata. Much disagreement can be found in the literature concerning how the $S_{3}$-layer is organised. Bucher (1957) and Harada and Côté (1985) suggested no lamellae and a flat S-helix of microfibrils. However several authors have claimed that the $\mathrm{S}_{3}$-layer, like the $\mathrm{S}_{1}$-layer, consists of various lamellae of different helical orientations (Liese 1963; Wardrop 1964; Wardrop \& Harada 1965; Dunning 1969). Meier (1955), however, reported that the microfibrils are nearly parallel to the cell axis in the $S_{3}$-layer of Norway spruce, while Paakkari and Serimaa (1984) reported $\mathrm{S}_{3}$ angles of $19^{\circ}$ in earlywood and $14^{\circ}$ in latewood. More recently Abe et al. (1991, 1992) elucidated the microfibrillar orientation of the $S_{3}$-layer of several conifers including Norway spruce. They found the final deposited microfibrils on the innermost surfaces of the tracheids could be oriented in either Z- or S-helices. Tracheids with a Z-helix were predominant in the later part of the annual ring, though an S-helix of 40-50 ${ }^{\circ}$ was much more common than a Z-helix (Abe et al. 1992). Moreover, when the last deposited microfibrils had an S-helix, the microfibrils beneath had a flatter $\mathrm{S}$-helix or steep Z-helix. This was explained as resulting from a gradual counterclockwise shift in microfibril angle from the outer $S_{2}$ to the inner $S_{3}$.

\section{Pits}

In Norway spruce there are two types of pit pairs in longitudinal tracheids: bordered pit pairs and half-bordered pit pairs. Pits between two tracheids (longitudinal or radial) are bordered and pits between ray parenchyma and tracheids are half-bordered, the latter are also termed cross-field pits.

Bordered pits are larger and more abundant in the earlywood than in the latewood of Picea tracheids (Koran 1974). Koran studied the average diameter of bordered pits in radial walls of Picea mariana tracheids. In earlywood, bordered pits were c. 16.4 $\mu \mathrm{m}$ and in latewood c. $6.1 \mu \mathrm{m}$. Sirviö and Kärenlampi (1998) conducted a study on pits in Norway spruce and found that the relative size (pit width divided by tracheid width) of bordered pits decreased with greater cross-sectional tracheid wall area. The average size of bordered pits was $41 \%$ of tracheid width. The shape of the bordered pits was more circular the wider the tracheids. The orientation of both bordered and cross-field pits varied considerably and the authors concluded that angular orientation of pits is not a simple function of microfibril angle. Sirviö and Kärenlampi (1998) also found that the relative size of the largest pits and number of pits per unit length (pit density) increased towards the tracheid ends.

Studies have also been carried out of the ultrastructure of pits in Norway spruce tracheids (Jutte \& Spit 1963; Fengel 1968; Banks 1971). Jutte and Spit (1963) showed that there are circularly oriented microfibrils in the torus and microfibrils in the pit border are also circularly oriented (Bailey \& Vestal 1937; Khalili et al. 2001). Greaves 
(1973) found that margo structure in bordered pits were denser in latewood and not as easily aspirated as pits in earlywood. Fengel (1972) and Harada and Côté (1985) have reviewed the structure and function of bordered and half-bordered pits in softwoods.

Bars of Sanio or crassulae are found as dark zones above and below bordered pits on the radial walls. They are, as in many other conifers, found in Norway spruce tracheids.

Even though the majority of bordered pits in Norway spruce occur on the radial walls, tangential pitting is not uncommon (Laming \& Welle 1971). Normally in a growth ring, tangential pitting is restricted to the last 4 or 5 tracheids in a radial row of tracheids, i.e. in the latewood. However, tangential pitting in earlywood also exists and it has been reported to occur as early as the eighth tracheid in a radial row. Fujikawa and Ishida (1974) studied the ultrastructure of the tangential bordered pits in various softwoods and found the torus to be approximately circular in Picea sp; however, tori with circularly oriented fibrils were only rarely found. The most important and interesting observation was that the margo did not have any openings. Thus, liquid flow should not be expected through bordered pits of tangential walls. Koran (1977) studied tangential pitting in Picea mariana and found the average bordered pit to be c. $5.4 \mu \mathrm{m}$ in diameter. This is only one third the size of a bordered pit in the radial wall of an earlywood tracheid and half the size of a bordered pit in the radial wall of a latewood tracheid.

\section{CONCLUDING REMARKS}

The morphology of Norway spruce tracheids, like that of many other biological structures, exhibits a wide range of variability. For further information on variation of the micro- and ultrastructural properties of Norway spruce and the implications for pulp and paper, three recent doctoral theses are recommended, i.e., Spångberg (1998), Sirviö (2000), and Bergander (2001). An important future task will be to document and visualise the variation in morphology of tracheids in models, with attention paid to all structures and parts of tracheids, including tracheid tips, pit-regions and plain cell wall areas. This knowledge must also be considered and used in industrial processes. The pulp and paper industry can use the large variability and general trends in morphological properties to advantage, since this allows different parts of the stem to be used for different products. Though this is partly the practice today in several pulp and paper industries, the potential for such specialised use of wood raw material is much greater.

It has become evident while working on this review that to understand the microand ultrastructural properties of tracheids, the mechanisms behind wood development, such as regulation of cambial activity or cell wall biosynthesis, are very important. To this end, recent biotechnological advances enabling the identification and characterisation of the enzymes involved in cell wall formation may lead to a general and deeper understanding of both cell wall biosynthesis and tracheid morphology. 


\section{ACKNOWLEDGEMENTS}

This work was carried out within the framework of the Wood Ultrastructure Research Centre (WURC), a VINNOVA (NUTEK) competence centre at the Swedish University of Agricultural Sciences (http: //www-wurc.slu.se/). For general guidance and fruitful discussions, I thank Professor Thomas Nilsson and Professor Geoffrey Daniel, WURC, Department of Wood Science, Swedish University of Agricultural Sciences, Uppsala. For valuable comments and discussions I thank Professor emeritus Julius Boutelje, Stockholm, Dr. Adya P. Singh, New Zealand Forest Research Institute, Rotorua, New Zealand and Dr. Stig L. Bardage, WURC, Department of Wood Science, Swedish University of Agricultural Sciences, Uppsala.

\section{REFERENCES}

Abe, H., R. Funada, H. Imaizumi, J. Ohtani \& K. Fukazawa. 1995a. Dynamic changes in the arrangement of cortical microtubules in conifer tracheids during differentiation. Planta 197: 418-421.

Abe, H., R. Funada, J. Ohtani \& K. Fukazawa. 1995b. Changes in the arrangement of microtubules and microfibrils in differentiating conifer tracheids during the expansion of cells. Ann. Bot. 75: 305-310.

Abe, H., R. Funada, J. Ohtani \& K. Fukazawa. 1997. Changes in the arrangement of cellulose microfibrils associated with the cessation of cell expansion in tracheids. Trees 11: 328332.

Abe, H., J. Ohtani \& K. Fukazawa. 1991. FE-SEM observations on the microfibrillar orientation in the secondary wall of tracheids. IAWA Bull. n.s. 12: 431-438.

Abe, H., J. Ohtani \& K. Fukazawa. 1992. Microfibrillar orientation of the innermost surface of conifer tracheid walls. IAWA Bull. n.s. 13: 411-417.

Atmer, B. \& T. Thörnqvist. 1982. The properties of tracheids in spruce (Picea abies) and pine (Pinus sylvestris). Department of Forest Products, SLU, Uppsala 134: 80 [In Swedish].

Bailey, I.W. 1920. The cambium and its derivative tissues. II. Size variations of cambial initials in gymnosperms and angiosperms. Am. J. Bot. 7: 355-366.

Bailey, I.W. 1938. Cell wall structure of higher plants. Ind. Eng. Chem. 30: 40-47.

Bailey, I.W. \& M.G. Vestal. 1937. The orientation of cellulose in the secondary wall of tracheary cells. J. Arnold Arbor. 18: 185-195.

Banks, W.B. 1971. Structure of the bordered pit membrane in certain softwoods as seen by scanning electron microscopy. J. Inst. Wood Sci. 5: 12-15.

Bannan, M.W. 1963. Cambial behaviour with reference to cell length and ring width in Picea. Canad. J. Bot. 41: 811-822.

Bannan, M.W. 1965. The length, tangential diameter, and length/width ratio of conifer tracheids. Canad. J. Bot. 43: 967-984.

Bannan, M.W. 1967. Sequential changes in rate of anticlinal division, cambial cell length, and ring width in the growth of coniferous trees. Canad. J. Bot. 45: 1359-1369.

Bergander, A. 2001. Local variability in chemical and physical properties of spruce fibres. $\mathrm{PhD}$ Thesis, Department of Pulp and Paper Chemistry and Technology, Royal Institute of Technology, Stockholm.

Bergander, A., J. Brändström, G. Daniel \& L. Salmén. 2001. Fibril angle variability in earlywood of Norway spruce using soft rot cavities and polarization confocal microscopy. J. Wood Science (In press).

Bergander, A. \& L. Salmén. 2000. Variations in transverse fibre wall properties: Relations between elastic properties and structure. Holzforschung 54: 654-660. 
Booker, R.E. \& J. Sell. 1998. The nanostructure of the cell wall of softwoods and its functions in a living tree. Holz Roh Werkst. 56: 1-8.

Boutelje, J. 1968. Juvenile wood, with particular reference to northern spruce. Svensk Papperstidning 71: 581-585.

Bucher, H. 1957. Die Struktur der Tertiarwand von Holzfasern. Holzforschung 11: 97-102.

Chafe, S.C. 1974. On the lamellate structure of the $S_{2}$ layer. Protoplasma 79: 145-158.

Daniel, G. \& T. Nilsson. 1984. Studies on the $S_{2}$ layer of Pinus sylvestris. Department of Forest Products, report. Uppsala 154: 34.

Denne, M.P. 1973. Tracheid dimensions in relation to shoot vigour in Picea. Forestry 46: $117-$ 124.

Donaldson, L.A. \& M.J.F. Lausberg. 1998. Comparison of conventional transmitted light and confocal microscopy for measuring wood cell dimensions by image analysis. IAWA J. 19: 321-326.

Dunning, C.E. 1969. The structure of longleaf pine latewood. I. Cell-wall morphology and the effect of alkaline extraction. Tappi J. 52: 1326-1335.

Emerton, H.W. \& V. Goldsmith. 1956. The structure of the outer secondary wall of pine tracheids from kraft pulps. Holzforschung 10: 108-115.

Emons, A.M.C. 1994. Winding threads around plant cells: a geometrical model for microfibril deposition. Plant, Cell Environment 17: 3-14.

Emons, A.M.C., J. Derksen \& M.M.A. Sassen. 1992. Do microtubules orient plant cell wall microfibrils? Physiologia plantarum 84: 486-493.

Emons, A.M.C. \& B.M. Mulder. 1998. The making of the architecture of the plant cell wall: How cells exploit geometry. Proc. Nat. Acad. Sci. USA 95: 7215-7219.

Emons, A.M.C. \& B.M. Mulder. 2000. How the deposition of cellulose microfibrils builds cell wall architecture. Trends Plant Sci. 5: 35-40.

Fahlén, J. \& L. Salmén. 2001. The lamella structure of the wood fiber wall - radial or concentric. In: Proceedings of COST Action E20 Workshop, Interaction between cell wall components, 26th-28th April, 2001 at SLU, Uppsala, Sweden.

Fengel, D. 1968. Variation in the shape of bordered pits in various conifers. Holz Roh Werkst. 26: $296-304$.

Fengel, D. 1969. The ultrastructure of cellulose from wood. Part 1: Wood as the basic material for the isolation of cellulose. Wood Sci. Technol. 3: 203-217.

Fengel, D. 1972. Structure and function of the membrane in softwood bordered pits. Holzforschung 26: 1-9.

Fengel, D. \& M. Stoll. 1973. Variation in cell cross-sectional area, cell-wall thickness and wall layers of spruce tracheids within an annual ring. Holzforschung 27: 1-7.

Frei, E., R.D. Preston \& G.W. Ripley. 1957. The fine structure of the walls of conifer tracheids. VI. Electron microscope investigations of sections. J. Exp. Bot. 8: 139-146.

Frimpong-Mensah, K. 1987. Fibre length and basic density variation in the wood of Norway spruce (Picea abies (L.) Karst.) from northern Norway. Meddelelser fra Norsk Institutt for Skogforskning 40: 25.

Fujikawa, S. \& S. Ishida. 1974. Membrane structure of bordered pit on the tangential wall of tracheid of Coniferae species. J. Japan Wood Res. Soc. 20: 103-110.

Fujino, T. \& T. Itoh. 1998. Changes in the three dimensional architecture of the cell wall during lignification of xylem cells in Eucalyptus tereticornis. Holzforschung 52: 111-116.

Fujiwara, S. \& K.C. Yang. 2000. The relationship between cell length and ring width and circumferential growth rate in five Canadian species. IAWA J. 21: 335-345.

Funada, R., O. Furusawa, M. Shibagaki, H. Miura, T. Miura, H. Abe \& J. Ohtani. 2000. The role of cytoskeleton in secondary xylem differentation in conifers. In: R.A. Savidge, J.R. 
Barnett \& R. Napier (eds), Cell and molecular biology of wood formation: 255-264. BIOS Scientific Publishers Ltd, Oxford.

Gindl, W. \& R. Wimmer. 2000. Relationship between lignin content and tracheid morphology in spruce. In: Proceedings of 3rd Plant Biomechanics Conference, Aug.-Sept., 2000: 163168. Freiburg, Germany.

Greaves, H. 1973. Comparative morphology of selected sapwood species using the scanning electron microscope. Holzforschung 27: 80-88.

Grosser, D. 1986. On the occurrence of trabeculae with special consideration of diseased trees. IAWA Bull. n.s. 7: 319-341.

Hafrén, J., T. Fujino \& T. Itoh. 1999. Changes in cell wall architecture of differentiating tracheids of Pinus thunbergii during lignification. Plant Cell Physiol. 40: 532-541.

Hanley, S. J. \& D. G. Gray. 1994. Atomic force microscope images of Black spruce wood sections and pulp fibres. Holzforschung 48: 29-34.

Harada, H. \& W.A. Côté Jr. 1985. Structure of wood. In: T. Higuchi (ed.), Biosynthesis and biodegradation of wood components: 1-42. Academic Press, Orlando.

Helander, B.A. 1933. Variations in tracheid length of pine and spruce. Foundation for Forest Products Research of Finland 14: 75.

Herman, M., P. Dutilleul \& T. Avella-Shaw. 1998. Intra-ring and inter-ring variations of tracheid length in fast-grown versus slow-grown Norway spruce (Picea abies). IAWA J. 19: 3-23.

Herman, M., P. Dutilleul \& T. Avella-Shaw. 1999. Growth rate effects on intra-ring and interring trajectories of microfibril angle in Norway spruce (Picea abies). IAWA J. 20: 3-21.

Hirakawa, Y. \& Y. Fujisawa. 1995. The relationships between microfibril angles of the $\mathrm{S}_{2}$ layer and latewood tracheid lengths in elite sugi tree (Cryptomeria japonica) clones. Mokuzai Gakkaishi 41: 123-131.

Huang, C., N.P. Kutcha, G.L. Leaf \& R.A. Megraw. 1998. Comparison of microfibril angle measurement techniques. In: B.G. Butterfield (ed.), Microfibril angle in wood: 177-205. IAWA \& IUFRO, Christchurch, New Zealand.

Jakob, H.F., P. Fratzl \& S.E. Tschegg. 1994. Size and arrangement of elementary cellulose fibrils in wood cells: A small-angle X-ray scattering study of Picea abies. J. Struct. Biol. 113: $13-22$.

Jurbergs, K.A. 1960. Morphological properties of cotton and wood fibres. II. Slash pine. Tappi J. 43: 561-568.

Jutte, S. M. \& B. J. Spit. 1963. The submicroscopic structure of bordered pits on the radial walls of tracheids in Parana Pine, Kauri and European Spruce. Holzforschung 17: 168-175.

Kantola, M. \& H. Kähkönen. 1963. Small-angle X-ray investigation of the orientation of crystallites in Finnish coniferous and deciduous wood fibres. Ann. Acad. Sci. Fenn. A VI 137: $1-14$.

Kantola, M. \& S. Seitsonen. 1969. On the relation between tracheid length and microfibrillar orientation measured by X-ray diffraction in conifer wood. Ann. Acad. Sci. Fenn. 300: $2-10$.

Kataoka, Y., H. Saiki \& M. Fujita. 1992. Arrangement and superimposition of cellulose microfibrils in the secondary walls of coniferous tracheids. Mokuzai Gakkaishi 38: 327-335.

Keith, C.T. 1975. Tangential wall thickenings in conifer tracheids at ray-contact areas. Wood Fiber Sci. 7: 129-135.

Kerr, A. J. \& D. A.I. Goring. 1975. Ultrastructural arrangement of the wood cell wall. Cellulose Chem. and Technol. 9: 563-573.

Kerr, T. \& I.W. Bailey. 1934. The cambium and its derivative tissues. X. Structure, optical properties and chemical composition of the so-called middle lamella. J. Arnold Arbor. 15: $327-349$. 
Khalili, S., T. Nilsson \& G. Daniel. 2001. The use of soft rot fungi for determining the microfibrillar orientation in the $S_{2}$ layer of pine tracheids. Holz Roh Werkst. 58: 439-447.

Koran, Z. 1974. Intertracheid pitting in the radial walls of Black Spruce tracheids. Wood Fiber Sci. 7: 111-115.

Koran, Z. 1977. Tangential pitting in Black Spruce tracheids. Wood Sci. Technol. 11: 115-123.

Kucera, B. 1994. A hypothesis relating current annual height increment to juvenile wood formation in Norway spruce. Wood Fiber Sci. 26: 152-167.

Kyrkjeeide, P.A. 1990. A wood quality study of suppressed, intermediate and dominant trees of plantation grown Picea abies. Forest Products Laboratory, Madison WI, USA.

Ladell, J.L. 1967. Ray thickenings in the walls of conifer tracheids. Nature 213: 470-473.

Laming, P.B. \& B. J.H. ter Welle. 1971. Anomalous tangential pitting in Picea abies (L.) Karst. (European Spruce). IAWA Bull. n.s. 4: 3-10.

Larsen, M. J., J.E. Winandy \& F. Green. 1995. A proposed model of the tracheid cell wall of southern yellow pine having an inherent radial structure in the $S_{2}$ layer. Mater Organismen 29: 197-210.

Ledbetter, M.C. \& K.R. Porter. 1963. A "microtubule" in plant cell fine structure. J. Cell Biol. 19: 239-250.

Lewis, F.T. 1935. The shape of tracheids in the pine. Am. J. Bot. 22: 741-762.

Lichtenegger, H., A. Reiterer, T.S.E. Stanzl \& P. Fratzl. 1999. Variation of cellulose microfibril angles in softwoods and hardwoods: A possible strategy of mechanical optimization. J. Struct. Biol. 128: 257-269.

Liese, W. 1963. Tertiary wall and warty layer in wood cells. J. Polymer Sci. 2: 213-219.

Lindgren, P. 1958. X-ray orientation investigations on some Swedish cellulose materials. Ark. Kemi 12: 437-452.

Lindström, H. 1997. Fiber length, tracheid diameter, and latewood percentage in Norway spruce: development from pith outwards. Wood Fiber Sci. 29: 21-34.

Lindström, H., J.W. Evans \& S.P. Verrill. 1998. Influence of cambial age and growth conditions on microfibril angle in young Norway spruce (Picea abies [L.] Karst.). Holzforschung 52: 573-581.

Marton, R. \& S.D. McGovern. 1970. Relation of crystallite dimensions and fibrillar orientation to fiber properties. Tappi stap no. 8: 153-158.

Marton, R., P. Rushton, J. S. Sacco \& K. Sumiya. 1972. Dimensions and ultrastructure in growing fibers. Tappi J. 55: 1499-1504.

Maurer, A. \& D. Fengel. 1991. Electron microscope representation of structural details in softwood cell walls with very thin ultra-microtome sections. Holz Roh Werkst. 49: 53-56.

Meier, H. 1955. Über den Zellwandabbau durch Holzvermorschungspilze und die submikroskopische Struktur von Fichtentracheiden und Birkenholzfasern. Holz Roh Werkst. 13: 323-338.

Nakashima, J., T. Mizuno, K. Takabe, M. Fujita \& H. Saiki. 1997. Direct visualization of lignifying secondary wall thickenings in Zinnia elegans cells in culture. Plant Cell Physiol. 38: $818-827$.

National Board of Forestry. 2000. Skogsstatistisk årsbok 2000. Statistical Yearbook of Forestry 2000. National Board of Forestry, Jönköping, Sweden [In Swedish].

Necesany, V. 1961. The variation of "normal" wood in view of its structure. Faserforschung und Textiltechnik 12: 169-178.

Nylinder, P. \& E. Hägglund. 1954. Ståndorts- och trädegenskapers inverkan på utbyte och kvalitet vid framställning av sulfitmassa av gran. Effect of site and tree properties on yield and quality of Norway Spruce sulphite pulp. Meddelanden från statens skogsforsknings institut, Stockholm 44: 184. 
Olesen, P.O. 1977. The variation of the basic density level and tracheid width within the juvenile and mature wood of Norway spruce. Forest Tree Improvement, Arboretet Hoersholm 12: 21.

Ollinmaa, P. J. 1961. Study on reaction wood. Acta Forestalia Fennica 72: 1-54 [In Finnish].

Paakkari, T. \& R. Serimaa. 1984. A study of the structure of wood cells by X-ray diffraction. Wood Sci Technol. 18: 79-85.

Panshin, A.J. \& C. de Zeeuw. 1980. Textbook of Wood Technology, 4th Ed. McGraw-Hill Book Company, New York.

Petrić, B. \& V. Śćukanec. 1973. Volume percentage of tissues in wood of conifers grown in Yugoslavia. IAWA Bull. 1973/2: 3-7.

Preston, R.D. 1934. The organization of the cell wall of the conifer tracheid. Phil. Trans. Roy. Soc. Lond. Biol. 224: 131-173.

Prodhan, A., R. Funada, J. Ohtani, H. Abe \& K. Fukazawa. 1995. Orientation of microfibrils and microtubules in developing tension-wood fibres of Japanese ash (Fraxinus mandshurica var. japonica). Planta 196: 577-585.

Pyszynski, W. \& Z. Hejnowicz. 1972. Is the orientation of the fibrillar helix in the main layer of cell walls constant or variable within a tree? Acta Soc. Bot. Poloniae 41: 27-38.

Reiterer, A., H.F. Jakob, S.E. Stanzl Tschegg \& P. Fratzl. 1998. Spiral angle of elementary cellulose fibrils in cell walls of Picea abies determined by small-angle X-ray scattering. Wood Sci Technol. 32: 335-345.

Roland, J.C., D. Reis, B. Vian, B. Satiat-Jeunemaitre \& M. Mosiniak. 1987. Morphogenesis of cell walls at the supramolecular level: internal geometry and versatility of helicoidal expression. Protoplasma 140: 75-97.

Ruel, K., F. Barnoud \& D.A.I. Goring. 1978. Lamellation in the $S_{2}$ layer of softwood tracheids as demonstrated by scanning transmission electron microscopy. Wood Sci Technol. 12: 287-291.

Sahlberg, U., L. Salmén \& A. Oscarsson. 1997. The fibrillar orientation in the $\mathrm{S}_{2}$-layer of wood fibres as determined by X-ray diffraction analysis. Wood Sci Technol. 31: 77-86.

Saranpää, P. 1994. Basic density, longitudinal shrinkage and tracheid length of juvenile wood of Picea abies (L.) Karst. Scand. J. For. Res. 9: 68-74.

Saranpää, P., E. Personen, M. Sarén, S. Andersson, S. Siiriä, R. Serimaa \& T. Paakkari. 2000. Variation of the properties of tracheids in Norway spruce (Picea abies (L.) Karst.). In: R.A. Savidge, J.R. Barnett \& R. Napier (eds), Cell and molecular biology of wood formation: 337-345. BIOS Scientific Publishers Ltd, Oxford.

Saranpää, P., R. Serimaa, S. Andersson, E. Pesonen, T. Suni \& T. Paakari. 1998. Variation of microfibril angle of Norway spruce (Picea abies (L.) Karst.) and Scots pine (Pinus sylvestris L.) - comparing X-ray diffraction and optical methods. In: B.G. Butterfield (ed.), Microfibril angle in wood: 240-252. IAWA \& IUFRO, Christchurch, New Zealand.

Schultze-Dewitz, G. \& H. Gotze. 1973. Studies on the fibre length, density and compression strength of inter- and circumnodal wood in Pinus sylvestris, Picea abies and Pseudotsuga menziesii. Drevarsky Vyskum 18: 33-44.

Schwarze, F. \& J. Engels. 1998. Cavity formation and the exposure of peculiar structures in the secondary wall $\left(\mathrm{S}_{2}\right)$ of tracheids and fibres by wood degrading basidiomycetes. Holzforschung 52: 117-123.

Sell, J. 1994a. Mechanical aspects of new SEM observations on the fibril/matrix structure of the $\mathrm{S}_{2}$ layer of softwood tracheids. Proc. Int. Congr. Plant Biomechanics, Montpellier: 163164.

Sell, J. 1994b. Confirmation of a sandwich-like model of the cell wall of softwoods by the light microscope. Holz Roh Werkst. 52: 234-234. 
Sell, J. \& T. Zimmerman. 1993. Radial fibril agglomerations of the $S_{2}$ on transverse-fracture surfaces of tracheids of tension-loaded spruce and white fir. Holz Roh Werkst. 51: 384.

Singh, A.P. 1997. The ultrastructure of the attack of Pinus radiata mild compression wood by erosion and tunnelling bacteria. Can. J. Bot. 75: 1095-1102.

Singh, A.P. \& R.E. Booker. 2000. Effect of wood structure variability on properties. Wood Processing Newsletter, Forest Research, Rotorua, NZ No. 28.

Singh, A.P. \& G. Daniel. 2001. The $\mathrm{S}_{2}$ layer in the tracheid walls of Picea abies wood: Inhomogeneity in lignin distribution and cell wall microstructure. Holzforschung 55: 373-378.

Singh, A.P. \& L.A. Donaldson. 1999. Ultrastructure of tracheid cell walls in radiata pine (Pinus radiata) mild compression wood. Can. J. Bot. 77: 32-40.

Singh, A.P., J. Sell, U. Schmitt, T. Zimmermann \& B. Dawson. 1998. Radial striation of the $\mathrm{S}_{2}$ layer in mild compression wood tracheids of Pinus radiata. Holzforschung 52: 563 566.

Sirviö, J. 2000. Variation in tracheid properties of Norway spruce (Picea abies (L.) Karst.). PhD Thesis, Department of Forest Resource Management, University of Helsinki, Helsinki.

Sirviö, J. \& P. Kärenlampi. 1998. Pits as natural irregularities in softwood fibers. Wood Fiber Sci. 30: 27-39.

Spångberg, K. 1998. Sorting Norway spruce pulpwood. PhD Thesis, Department of Forest Products, Swedish University of Agricultural Sciences, Uppsala.

Stone, J.E., A.M. Scallan \& P.A.V. Ahlgren. 1971. The ultrastructural distribution of lignin in tracheid cell walls. Tappi J. 54: 1527-1530.

Tang, R.C. 1973. The microfibrillar orientation in cell-wall layers of Virginia Pine tracheids. Wood Fiber Sci. 5: 181-186.

Tyrväinen, J. 1995. Wood and fiber properties of Norway spruce and its suitability for thermomechanical pulping. Acta Forestalia Fennica 249: 155.

Vasiljevic, S. 1955. Tracheid length within the growth ring. Glasn sum Fak, Beograd 10: 161-190.

Wardrop, A.B. 1957. The organization and properties of the outer layer of the secondary wall in conifer tracheids. Holzforschung 11: 102-110.

Wardrop, A.B. 1958. The organization of the primary wall in differentiating conifer tracheids. Aust. J. Bot. 6: 299-305.

Wardrop, A.B. 1964. The structure and formation of the cell wall in xylem. In: M.H. Zimmermann (ed.), The formation of wood in forest trees: 87-134. Academic Press, New York.

Wardrop, A.B. 1969. Fiber morphology and papermaking. Tappi J. 52: 396-408.

Wardrop, A.B. \& H.E. Dadswell. 1950. The nature of reaction wood. II. The cell wall organization of compression wood tracheids. Aust. J. Sci. Res. B3: 1-13.

Wardrop, A.B. \& H. Harada. 1965. The formation and structure of the cell wall in fibres and tracheids. J. Exp. Bot. 16: 356-371.

Wymer, C. \& C. Lloyd. 1996. Dynamic microtubules: implications for cell wall patterns. Trends Plant Sci. 7: 222-228.

Zimmermann, T. \& J. Sell. 2000. Comparison of the biomechanical properties of the fine structure of the cell wall of normal and reaction wood. In: Proceedings of 3rd Plant Biomechanics Conference, Aug.-Sept. 2000: 186-192. Freiburg, Germany. 